OPEN ACCESS

Edited by:

Luca Antonioli,

University of Pisa, Italy

Reviewed by:

Narut Prasitlumkum,

University of California, Riverside,

United States

Shahin Hajibandeh,

Wye Valley NHS Trust,

United Kingdom

Masoud Sadeghi,

Kermanshah University of Medical

Sciences, Iran

*Correspondence:

Tongwen Sun

suntongwen@163.com

tThese authors have contributed

equally to this work

Specialty section:

This article was submitted to Inflammation Pharmacology,

a section of the journal

Frontiers in Pharmacology

Received: 13 November 2020

Accepted: 10 May 2021

Published: 25 May 2021

Citation:

Ding $X$, Cui $Y$, Liang $H$, Wang $D, L i L$, Kan Q, Wang $L$ and Sun T (2021)

Association Between Prior Calcium Channel Blocker Use and Mortality in Septic Patients: A Meta-Analysis of

Cohort Studies.

Front. Pharmacol. 12:628825. doi: 10.3389/fphar.2021.628825

\section{Association Between Prior Calcium Channel Blocker Use and Mortality in Septic Patients: A Meta-Analysis of Cohort Studies}

\author{
Xianfei Ding ${ }^{1 \dagger}$, Yuqing Cui ${ }^{1 \dagger}$, Huoyan Liang ${ }^{1}$, Dong Wang ${ }^{1}$, Lifeng $\mathrm{Li}^{2}$, Quancheng Kan ${ }^{3}$, \\ Lexin Wang ${ }^{4}$ and Tongwen Sun ${ }^{1 *}$ \\ ${ }^{1}$ General Intensive Care Unit, The First Affiliated Hospital of Zhengzhou University, Henan Key Laboratory of Critical Care \\ Medicine, Zhengzhou Key Laboratory of Sepsis, Henan Engineering Research Centre for Critical Care Medicine, Zhengzhou, \\ China, ${ }^{2}$ Internet Medical and System Applications of National Engineering Laboratory, Cancer Center, The First Affiliated Hospital \\ of Zhengzhou University, Zhengzhou, China, ${ }^{3}$ Department of Pharmacy, The First Affiliated Hospital of Zhengzhou University, \\ Zhengzhou, China, ${ }^{4}$ School of Biomedical Sciences, Charles Sturt University, Wagga Wagga, NSW, Australia
}

Background: The aim of this study was to comprehensively review the literature and synthesize the evidence concerning the relationship between prior calcium channel blocker (CCB) use and mortality in patients with sepsis.

Methods: The Medical Literature Analysis and Retrieval System Online (MEDLINE), Excerpta Medica database (EMBASE), Cochrane CENTRAL, and Web of Science databases were searched from their inception to April 9, 2020. Cohort studies related to prior calcium channel blocker use in patients with sepsis were analyzed. Pairs of reviewers independently screened the studies, extracted the data, and assessed the risk of bias. The primary outcome of 90-days mortality or secondary outcome of short-term mortality, including 30-days, Intensive Care Unit (ICU), and in-hospital mortality, were analyzed. Heterogeneity among studies was assessed using the $l^{2}$ statistic and was considered moderate if $I^{2}$ was $50-75 \%$ and high if $I^{2}$ was $\geq 75 \%$. Random-effects models were used to calculate the pooled odds ratios (ORs) and 95\% confidence intervals (Cls). The quality of the studies was evaluated with the Newcastle-Ottawa Scale (NOS). Sensitivity analyses were performed to examine the robustness of the results.

Results: In total, 639 potentially relevant studies were identified, and the full texts of 25 articles were reviewed. Ultimately, five cohort studies involving 280,982 patients were confirmed to have a low risk of bias and were included. Prior CCB use was associated with a significantly lower 90-days mortality in sepsis patients [OR, $0.90(0.85-0.95) ; l^{2}=31.9 \%$ ]. Moreover, prior CCB use was associated with a significantly reduced short-term mortality rate in septic shock patients [OR, $\left.0.61(0.38-0.97) ; I^{2}=62.4 \%\right]$ but not in sepsis patients [OR, $\left.0.83(0.66-1.04) ; l^{2}=95.4 \%\right]$.

\footnotetext{
Abbreviations: CCB, calcium channel blocker; CIs, confidence intervals; NOS, Newcastle-Ottawa Scale; PICOS, population,
} intervention, comparators, outcomes and study design; LPS, lipopolysaccharide. 
Conclusion: This meta-analysis suggests that prior CCB use is significantly associated with improved 90-days mortality in sepsis patients and short-term mortality in septic shock patients. This study provides preliminary evidence of an association between prior CCB use and mortality in sepsis patients.

Keywords: calcium channel blocker, sepsis, septic shock, mortality, systematic review, meta-analysis, prior

\section{BACKGROUND}

Sepsis is defined as a life-threatening disorder of organ function caused by a dysregulated host response to infection (Singer et al., 2016). Global epidemiological data suggest that sepsis is a major public health issue and remains a primary cause of mortality and critical illness; sepsis affects millions of people worldwide each year (Angus et al., 2001; Dellinger, 2003; Rhodes et al., 2017), and its incidence is not declining (Gaieski et al., 2013). Currently, the pathophysiological basis of sepsis is thought to involve disordered pro- and anti-inflammatory responses, which suggests a new method for the treatment of this deadly condition (Hotchkiss et al., 2013). The prognosis is associated with not only the virulence of the pathogens but also the septic patient's age and coexisting conditions, such cardiovascular dysfunction (Angus and van der Poll, 2013).

Calcium channel blockers (CCBs) are widely administered for the treatment of cardiovascular disease, including hypertension and ischaemic heart disease (Fihn et al., 2012; James et al., 2014). These drugs inhibit $\mathrm{Ca}^{2+}$ channels in the myocardium and vascular smooth muscle cells, resulting in the inhibition of myocardial contractions, the pulse conduction system (antiarrhythmias), and vasodilation (Sueta et al., 2017). Cardiovascular disease is well known to be one of the most common coexisting conditions in septic patients and is independently related to an increased risk of death during hospitalization (Martin et al., 2003; Vincent et al., 2009). Sepsis is related to an overload of $\mathrm{Ca}^{2+}$ in many cell types (Hotchkiss and Karl, 1996) that can lead to disordered cellular processes, cytotoxicity or even cell death via a variety of mechanisms, such as metabolic manifestations, vascular smooth muscle tone dysregulation, mitochondrial dysfunction, nuclear damage, cytoskeletal breakage, the production of nitric oxide and pro-inflammatory cytokines, and apoptosis (Dong et al., 2006; Clapham, 2007). However, CCBs can restore such disrupted cellular processes to their normal states through calcium channel-dependent calcium ion homeostasis. Furthermore, CCBs exert pleiotropic effects, such as antioxidant effects (Mason et al., 1998) and immunodepression and anti-inflammatory activity suppression (Das et al., 2009), in sepsis. Therefore, CCB use may benefit patients with sepsis.

Recently, Wiewel et al. (2017) reported that previous CCB use conferred an obvious survival benefit compared with non-CCB use in patients with sepsis. However, several studies (Lee et al., 2017; Kim et al., 2019; Hsieh et al., 2020) have indicated that prior CCB use was not related to lower mortality in septic patients. In addition, Hsieh et al. (2020) reported that CCBs were associated with decreased 30-days mortality in septic shock patients.
However, de Roquetaillade et al. (2020) indicated that CCB use was not associated with lower mortality in septic shock patients. Therefore, the relationship between previous CCB use and prognosis in sepsis patients is controversial. Thus, the available data were synthesized to evaluate whether CCBs are helpful for reducing mortality in septic patients.

\section{MATERIALS AND METHODS}

The study protocol is registered on the PROSPERO website (http://www.crd.york.ac.uk/PROSPERO) with the registration number CRD42019127112, and it can be found online at https://www.crd.york.ac.uk/PROSPERO/display_record.php? RecordID $=127112$.

\section{Search Strategy}

The meta-analysis of observational studies in epidemiology (MOOSE) guidelines were followed (Stroup et al., 2000). In addition, the PRISMA 2009 checklist is shown in Supplementary Table S1. A comprehensive literature search for cohort studies on the association between CCB use and mortality in septic patients published from the dates of database inception to April 9, 2020, was performed in the MEDLINE (www.ncbi.nlm.nih.gov/pubmed), EMBASE (www. embase.com), Cochrane CENTRAL (https://www. cochranelibrary.com/central), and Web of Science (https:// apps.webofknowledge.com) databases. A combination of $\mathrm{MeSH} /$ Emtree terms and title, abstract or keyword terms was used. The search terms were "calcium channel blockers," "calcium channel blocking agent," "calcium antagonist," "sepsis," and "septic shock." The detailed retrieval strategy can be seen in Supplementary Table S2. The search was restricted to studies published in English. Furthermore, we reviewed the references of eligible articles to identify other potentially relevant studies. The literature searches were conducted independently by Xianfei Ding and Yuqing Cui.

\section{Eligibility Criteria}

Studies were considered eligible for inclusion in the meta-analysis if they met the following population, intervention, comparators, outcomes and study design (PICOS) criteria: 1) the population included adult sepsis and/or septic shock patients, 2) the intervention involved the prior use of CCBs, 3) the comparison was with no prior use of CCBs, 4) the primary outcome was 90-days mortality, or secondary outcome was short-term (30-days, Intensive Care Unit (ICU), in-hospital) mortality, 5) the study design was an observational cohort study. We excluded relevant studies that did not report the 
mortality of sepsis or septic shock patients. In addition, we also excluded studies for which full texts could not be obtained and summary and review articles.

\section{PICOS Question}

Population: Adult sepsis and/or septic shock patients.

Intervention: Prior use of CCB.

Comparison: No prior use of CCB.

Outcome: Mortality.

Study design: Prospective observational or retrospective cohort studies.

\section{Study Selection and Data Extraction}

Xianfei Ding and Yuqing Cui independently screened the titles and/or abstracts of all retrieved studies to determine whether they met the eligibility criteria and noted the reason for the exclusion of each rejected article (Kappa statistic $=0.91$ ). Key data explications were performed independently by Huoyan Liang and Lifeng Li. All disputes were settled by discussions among Dong Wang, Quancheng Kan, and Lexin Wang. The following characteristics were extracted from all the included studies: first author, year (publication), country, study design, CCB and nonCCB use in patients with sepsis, sex composition of patients, study duration, and unadjusted or adjusted odds ratios (ORs) with $95 \%$ confidence intervals (CIs) for the primary and secondary outcomes.

\section{Assessment of Risk of Bias}

The risk of bias of the eligible studies was evaluated with the Newcastle-Ottawa Scale (NOS) for cohort studies (Wells and O'Connell, 2014). A maximum of nine points could be obtained: four points was the maximum for selection, two points was the maximum for design and analysis comparability, and three points was the maximum for the assessment of outcomes. High-quality studies received a score $\geq 7$, whereas moderate- and low-quality studies received scores of 4-6 and $\leq 4$, respectively. The Grading of Recommendations, Assessment, Development and Evaluation (GRADE) criterion was used to estimate and summarize the quality of the evidence (Brozek et al., 2009).

\section{Statistical Analysis}

For binary data, we used ORs and their 95\% CIs to estimate the effect sizes of our outcome of interest. The pooled ORs from the included studies were calculated with a randomeffects model, and the $I$ - $V$ heterogeneity method was used to generate the forest plots. Heterogeneity (Higgins et al., 2003) among studies was evaluated by the $I^{2}$ statistic; $I^{2}$ values of $0-25 \%$ represented no heterogeneity, values of $25-50 \%$ represented slight heterogeneity, values of $50-75 \%$ represented moderate heterogeneity, and values of $75-100 \%$ represented high heterogeneity. Begg's funnel plot (Begg and Mazumdar, 1994) was constructed, and Egger's linear regression (Stuck et al., 1998) was performed to evaluate potential publication bias. Funnel plots (Hunter et al., 2014) were visually evaluated for asymmetry. One-way sensitivity analysis (Copas and Shi, 2001) was performed to evaluate the robustness of the results. All statistical analyses were performed with Stata 14.0 (College Station, TX, 77,845, United States, Serial number: 401406267051).

\section{RESULTS}

\section{Study Selection}

The initial literature search yielded 639 potentially relevant publications, and 478 records remained after removing duplicates. We then excluded 453 records after the preliminary title and abstract screening. After evaluating the full texts of the remaining 25 records, we identified five cohort studies (Lee et al., 2017; Wiewel et al., 2017; Kim et al., 2019; de Roquetaillade et al., 2020; Hsieh et al., 2020) that were eligible for inclusion in this meta-analysis (Figure 1).

\section{Study Characteristics}

A detailed description of the five included studies is shown in Table 1. In total, 280,982 septic patients were included in this meta-analysis. All the included studies were multi-centre cohort studies that involved septic patients who reported their prior use of CCBs (Lee et al., 2017; Wiewel et al., 2017; Kim et al., 2019; de Roquetaillade et al., 2020; Hsieh et al., 2020). We extracted the adjusted or propensity-matched ORs and 95\% CIs from the primary and secondary outcome data. Otherwise, the data were calculated from the raw data in each included study.

\section{Risk of Bias Assessment}

The risk of bias assessment of the included studies is shown in Table 2. The five eligible observational cohort studies (Lee et al., 2017; Wiewel et al., 2017; Kim et al., 2019; de Roquetaillade et al., 2020; Hsieh et al., 2020) had scores $\geq 8$ and were considered to have a low risk of bias according to the NOS.

\section{Effects of CCB on Septic Patients}

The 90-days mortality rate, which was the primary outcome, and the short-term mortality rates, which were the secondary outcomes, are shown in Figures 2A-4A. Prior CCB use was associated with a significantly reduced 90 -days mortality rate in sepsis patients [OR, $0.90(0.85-0.95) ; I^{2}=31.9 \%$; evidence rank, very low] (Figure 2A). Moreover, prior CCB use was associated with a reduced short-term mortality rate in septic shock patients [OR, 0.61 (0.38-0.97); $I^{2}=62.4 \%$; evidence rank, very low] but not in sepsis patients [OR, $0.83(0.66-1.04) ; I^{2}=95.4 \%$; evidence rank, very low] (Figures 3A, 4A).

\section{Sensitivity Analysis}

As the included studies were observational cohort studies with a low risk of bias (Table 2), a sensitivity analysis of the methodological criteria was not conducted. A sensitivity analysis was conducted to evaluate the effect of any one study on the pooled ORs and 95\% CIs by removing one individual study at a time. The sensitivity analysis findings indicated that the results were robust and reliable (Figures 2B-4B). 


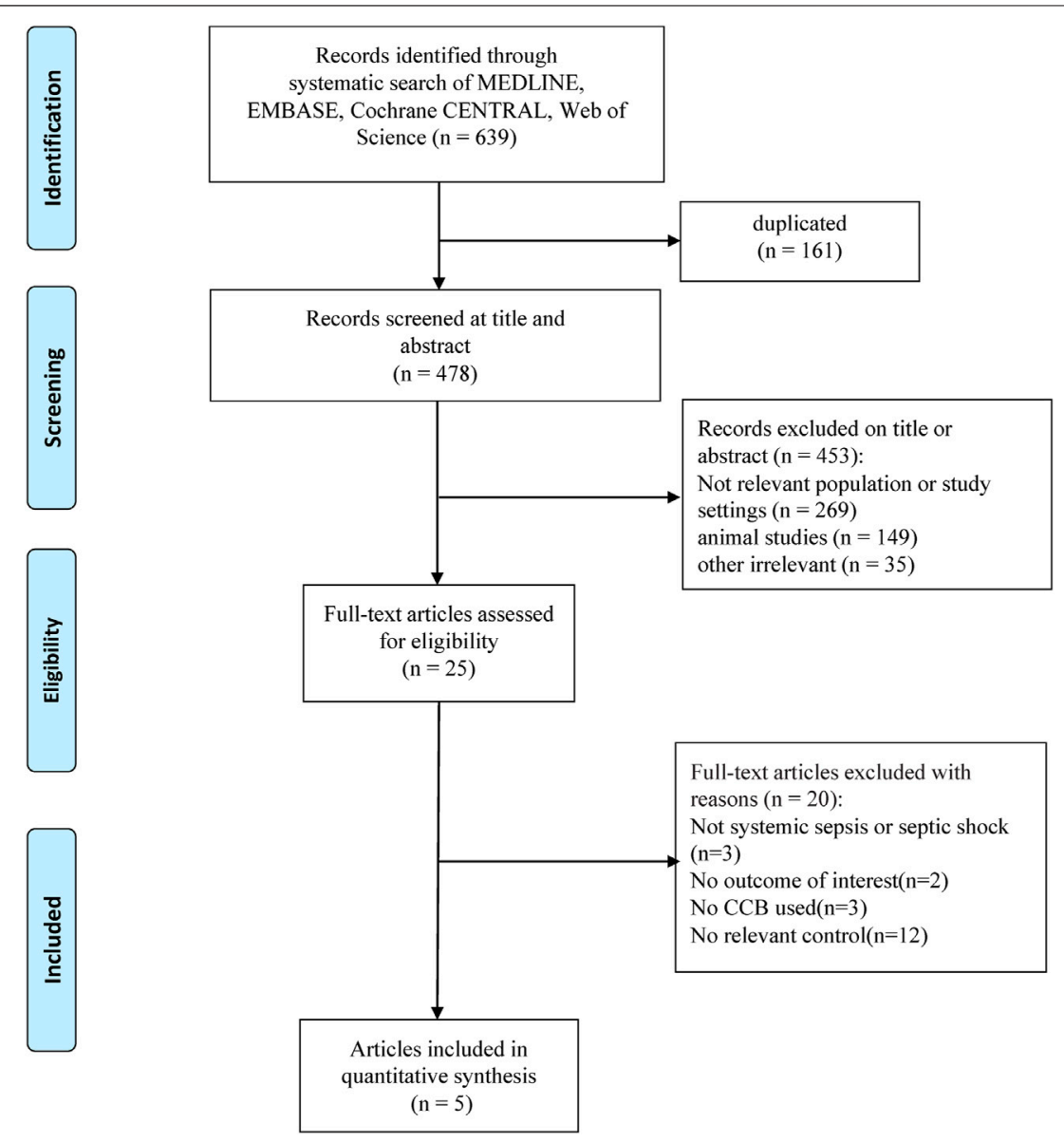

FIGURE 1 | Flow chart of the literature selection process.

\section{Publication Bias}

Because the number of included studies that reported the effects of CCB use on septic patients was small $(<10)$, we did not generate a funnel plot, as it may not have discovered publication bias (Lau et al., 2006).

\section{DISCUSSION}

This meta-analysis involving 280,982 patients indicated that compared with no prior CCB use, prior CCB use was related to a reduced 90 -days mortality rate in patients with sepsis and a reduced short-term mortality rate in patients with septic shock. To our knowledge, this is the first meta-analysis to explore and evaluate the relationship between prior CCB use and mortality in septic patients. These findings indicate that $\mathrm{CCB}$ administration is associated with significant improvements in the 90-days prognosis of sepsis patients and the short-term survival of septic shock patients.

Currently, the effect of prior CCB use on the mortality of septic patients remains unclear (Lee et al., 2017; Wiewel et al., 2017; Kim et al., 2019; de Roquetaillade et al., 2020; Hsieh et al., 2020). Several animal studies (Németh et al., 1998; Wyska, 2009) have suggested that CCBs could reduce mortality in endotoxaemic mouse models. Verapamil improved the survival rate of dogs with endotoxic shock (Bosson et al., 1985), and nifedipine increased survival in a bacteraemia model (Bosson et al., 1986). However, the results of clinical studies are not consistent with the results of these animal studies (Lee et al., 2017; Kim et al., 2019; Hsieh et al., 2020). This meta-analysis provides evidence supporting the association of prior CCB use with decreased mortality in patients with sepsis.

The potential mechanism underlying the association of $\mathrm{CCB}$ use and mortality in septic patients remains unclear. CCB may ameliorate cardiac dysfunction (Bosson et al., 1985; Zhu et al., 2005 ) in septic survivors with cardiovascular complications (Ou et al., 2016). A previous meta-analysis showed that prior $\beta$-blocker use was associated with a reduction in mortality, which may be due to decreased cardiac systolic and diastolic dysfunction (Tan et al., 2019). Several studies have reported that CCBs differentially inhibit the generation of pro-inflammatory factors, such as interleukin-12 (IL-12), interferon-gamma (IFN- $\gamma$ ) (Németh et al., 1998), and TNF-alpha (Li et al., 2009), in sepsis patients. Additionally, CCBs inhibit the nuclear transcription factor NF- $\kappa B$ and activate PI3K/Akt passage (Mustafa and Olson, 1999; Hayashi et al., 2000; Li et al., 2006; Hassoun et al., 2008), which reduce LPSinduced acute inflammatory reactions (Zhang et al., 2007). 
TABLE 1 | Summary of identified studies.

\begin{tabular}{|c|c|c|c|c|c|c|c|c|c|c|c|c|}
\hline Author/Year & Country & $\begin{array}{l}\text { Study } \\
\text { Design }\end{array}$ & $\begin{array}{l}\text { Study } \\
\text { Duration }\end{array}$ & $\begin{array}{c}\text { Female/ } \\
\text { Male }\end{array}$ & $\begin{array}{l}\text { Descriptions } \\
\text { of participants }\end{array}$ & $\begin{array}{l}\text { Disease } \\
\text { severity }\end{array}$ & $\begin{array}{l}\text { Number of } \\
\text { Patients in } \\
\text { CCB(death)/ } \\
\text { non-CCB } \\
\text { Use(death) }\end{array}$ & $\begin{array}{l}\text { Follow } \\
\text { up }\end{array}$ & $\begin{array}{c}\text { 90-day } \\
\text { Mortality in } \\
\text { sepsis }^{\text {a }}(\mathrm{OR}, \\
95 \% \mathrm{Cl} \text { ) }\end{array}$ & $\begin{array}{l}\text { Short-term } \\
\text { Mortality in } \\
\text { septic shock } \\
\text { (OR, 95\% CI) }\end{array}$ & $\begin{array}{l}\text { Short-term } \\
\text { Mortality in } \\
\text { sepsis }^{\mathrm{a}} \text { (OR, } \\
95 \% \mathrm{Cl})\end{array}$ & Comorbidities \\
\hline $\begin{array}{l}\text { Wiewel et al. } \\
\text { (2017) (18) }\end{array}$ & Netherlands & PC & $\begin{array}{c}2011 / \\
7-2013 / 7\end{array}$ & $420 / 640$ & Critical sepsis & $\begin{array}{c}\text { SOFA } 7(5-9) / \\
\quad 7(5-9)\end{array}$ & $197(58) / 863(326)$ & 90-day & $\begin{array}{c}0.62 \\
(0.40-0.96)\end{array}$ & $\begin{array}{c}0.31 \\
(0.14-0.65)\end{array}$ & $\begin{array}{c}0.48 \\
(0.31-0.74)^{\mathrm{a}}\end{array}$ & $\begin{array}{l}\text { Cerebrovascular disease } \\
\text { Chronic cardiovascular } \\
\text { insufficiency } \\
\text { Chronic renal insufficiency } \\
\text { Congestive heart failure } \\
\text { Chronic obstructive } \\
\text { pulmonary disease } \\
\text { Diabetes mellitus } \\
\text { Hematologic malignancy } \\
\text { Hypertension } \\
\text { Immune deficiency } \\
\text { Metastatic malignancy } \\
\text { Myocardial infarction } \\
\text { Nonmetastatic malignancy } \\
\text { Peripheral vascular disease }\end{array}$ \\
\hline $\begin{array}{l}\text { Lee et al. } \\
\text { (2017) (19) }\end{array}$ & Taiwan & $\mathrm{RC}$ & 2000-2011 & $\begin{array}{l}20,903 / \\
30,175\end{array}$ & Sepsis & $\begin{array}{c}\text { Average } \\
\text { number of } \\
\text { organ } \\
\text { dysfunction } 1 \\
(1-2) / 1(1-2)\end{array}$ & $19,742 / 31,336$ & 90-day & $\begin{array}{c}0.91 \\
(0.85-0.97)\end{array}$ & NA & $\begin{array}{c}0.92 \\
(0.85-0.99)\end{array}$ & $\begin{array}{l}\text { Myocardial infarction } \\
\text { Congestive heart failure } \\
\text { Peripheral vascular disease } \\
\text { Cerebrovascular disease } \\
\text { Dementia } \\
\text { Chronic pulmonary disease } \\
\text { Rheumatologic disease } \\
\text { Peptic ulcer disease } \\
\text { Diabetes with chronic } \\
\text { complications } \\
\text { Hemiplegia or paraplegia } \\
\text { Renal disease }\end{array}$ \\
\hline $\begin{array}{l}\text { Kim et al. } \\
\text { (2019) (20) }\end{array}$ & $\begin{array}{l}\text { South } \\
\text { Korea }\end{array}$ & $\mathrm{RC}$ & 2003-2013 & $2,328 / 2,221$ & Sepsis & NA & $\begin{array}{l}1,287(586) / \\
3,262(1,583)\end{array}$ & 90-day & $\begin{array}{c}0.89 \\
(0.78-1.01)\end{array}$ & NA & $\begin{array}{c}0.83 \\
(0.72-0.95)\end{array}$ & $\begin{array}{l}\text { Cardiovascular } \\
\text { Chronic respiratory } \\
\text { disease } \\
\text { Chronic renal disease } \\
\text { Chronic liver disease } \\
\text { Diabetes } \\
\text { Cerebrovascular } \\
\text { Solid tumor } \\
\text { Hematologic disease }\end{array}$ \\
\hline $\begin{array}{l}\text { Hsieh et al. } \\
\text { (2020) A (21) }\end{array}$ & Taiwan & $\mathrm{RC}$ & 1999-2013 & NA & Sepsis & NA & NA & 28-day & NA & NA & $\begin{array}{c}1.21 \\
(1.17-1.26)^{b}\end{array}$ & $\begin{array}{l}\text { Hyperlipidemia } \\
\text { Congestive heart failure } \\
\text { chronic kidney disease } \\
\text { chronic liver disease } \\
\text { chronic obstructive } \\
\text { pulmonary disease } \\
\text { ischemic heart disease } \\
\text { Hypertension } \\
\text { Cancer } \\
\text { tinued on following page) }\end{array}$ \\
\hline
\end{tabular}


TABLE 1 | (Continued) Summary of identified studies.

\begin{tabular}{|c|c|c|c|c|c|c|c|c|c|c|c|c|}
\hline Author/Year & Country & $\begin{array}{l}\text { Study } \\
\text { Design }\end{array}$ & $\begin{array}{l}\text { Study } \\
\text { Duration }\end{array}$ & $\begin{array}{c}\text { Female/ } \\
\text { Male }\end{array}$ & $\begin{array}{l}\text { Descriptions } \\
\text { of participants }\end{array}$ & $\begin{array}{l}\text { Disease } \\
\text { severity }\end{array}$ & $\begin{array}{l}\text { Number of } \\
\text { Patients in } \\
\text { CCB(death)/ } \\
\text { non-CCB } \\
\text { Use(death) }\end{array}$ & $\begin{array}{l}\text { Follow } \\
\text { up }\end{array}$ & $\begin{array}{c}\text { 90-day } \\
\text { Mortality in } \\
\text { sepsis }^{\mathrm{a}} \text { (OR, } \\
95 \% \mathrm{Cl} \text { ) }\end{array}$ & $\begin{array}{l}\text { Short-term } \\
\text { Mortality in } \\
\text { septic shock } \\
\text { (OR, } 95 \% \mathrm{Cl} \text { ) }\end{array}$ & $\begin{array}{l}\text { Short-term } \\
\text { Mortality in } \\
\text { sepsis }{ }^{\mathrm{a}} \text { (OR, } \\
95 \% \mathrm{Cl} \text { ) }\end{array}$ & Comorbidities \\
\hline $\begin{array}{l}\text { Hsieh et al } \\
\text { (2020) B (21) }\end{array}$ & Taiwan & $\mathrm{RC}$ & 1999-2013 & NA & Septic shock & NA & NA & 28-day & NA & $\begin{array}{c}0.64 \\
(0.53-0.77)\end{array}$ & NA & \\
\hline $\begin{array}{l}\text { Roquetaillade } \\
\text { et al. (2020) (22) }\end{array}$ & French & $\mathrm{RC}$ & 2008-2016 & NA & Septic shock & $\begin{array}{c}\text { SOFA } 9.57 \\
(3.71) / \\
10.96(4.06)\end{array}$ & $103 / 632$ & $I C U$ & NA & $\begin{array}{c}0.95 \\
(0.52-1.74)\end{array}$ & NA & $\begin{array}{l}\text { Chronic heart failures } \\
\text { Arterial hypertension } \\
\text { Diabetese } \\
\text { Obesity } \\
\text { Cirrhosis } \\
\text { Chronic obstructive } \\
\text { pulmonary disease chronic } \\
\text { kidney failure } \\
\text { Imunosuppression }\end{array}$ \\
\hline
\end{tabular}

Abbreviations: PC, prospective cohort; RC, retrospective cohort; SOFA, Sequential Organ Failure Assessment; $C C B$, calcium channel blockers; NA, not available; OR, odds ratio; Cl, confidence interval.

a30-day Mortality in sepsis that included septic shock.

${ }^{b} 30$-day Mortality in sepsis that not included septic shock.

TABLE 2 | The Newcastle-Ottawa Scale (NOS) for assessing the quality of including studies.

\begin{tabular}{|c|c|c|c|c|c|c|c|c|c|c|}
\hline \multirow{2}{*}{$\begin{array}{c}\text { Studies } \\
\text { First Author }\end{array}$} & \multicolumn{4}{|c|}{ Selection } & \multicolumn{2}{|c|}{ Comparability } & \multicolumn{3}{|c|}{ Assessment of outcome } & \multirow{2}{*}{$\begin{array}{l}\text { Total } \\
\text { Quality } \\
\text { Score }\end{array}$} \\
\hline & $\begin{array}{l}\text { Representativeness } \\
\text { of CCB Use Arm(s) }\end{array}$ & $\begin{array}{l}\text { Selection } \\
\text { of the non- } \\
\text { CCB Use } \\
\text { Arm(s) }\end{array}$ & $\begin{array}{l}\text { Origin of } \\
\text { Exposure } \\
\text { Source }\end{array}$ & $\begin{array}{l}\text { Demonstration } \\
\text { that Outcome of } \\
\text { Interest was not } \\
\text { Present at Start of } \\
\text { Study }\end{array}$ & $\begin{array}{l}\text { Studies } \\
\text { Controlling } \\
\text { the Most } \\
\text { Important } \\
\text { Factors }\end{array}$ & $\begin{array}{l}\text { Studies } \\
\text { Controlling } \\
\text { the Other } \\
\text { Main Factors }\end{array}$ & $\begin{array}{l}\text { Assessment of } \\
\text { Outcome with } \\
\text { Independency }\end{array}$ & $\begin{array}{l}\text { Adequacy of } \\
\text { Follow-up } \\
\text { Length (to } \\
\text { assess } \\
\text { outcome) }\end{array}$ & $\begin{array}{l}\text { Lost to } \\
\text { Follow-up } \\
\text { Acceptable } \\
\text { (less than 10\% } \\
\text { and reported) }\end{array}$ & \\
\hline $\begin{array}{l}\text { Wiewel et al. } \\
(2017)(18)\end{array}$ & * & * & * & * & * & * & * & * & * & 9 \\
\hline $\begin{array}{l}\text { Lee et al. } \\
\text { (2017) (19) }\end{array}$ & * & * & * & * & * & * & * & * & & 8 \\
\hline $\begin{array}{l}\text { Kim et al. } \\
\text { (2019) (20) }\end{array}$ & * & * & * & * & * & * & * & * & & 8 \\
\hline $\begin{array}{l}\text { Hsieh et al. } \\
\text { (2020) (21) }\end{array}$ & * & * & * & * & * & * & * & * & & 8 \\
\hline $\begin{array}{l}\text { Roquetaillade } \\
\text { et al. (2020) } \\
\text { (22) }\end{array}$ & * & * & * & * & * & * & * & * & & 8 \\
\hline
\end{tabular}


A

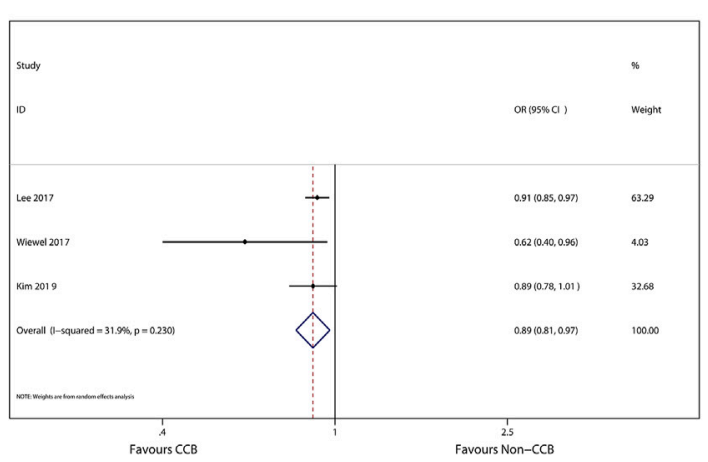

B Meta-analysis estimates, given named study is omitted

Lee 2017
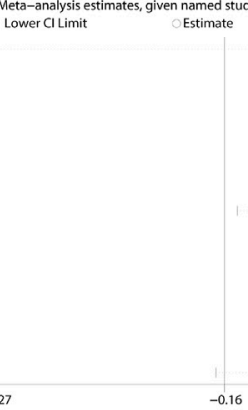

Wiewel 2017

Kim 2019
-0.27
| Upper Cl Limit

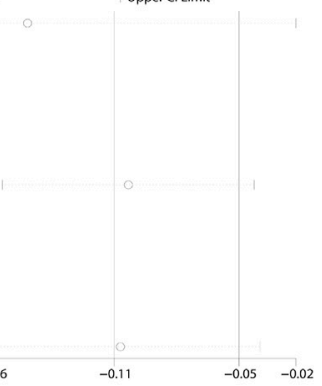

FIGURE 2 | (A) Forest plot showing the significance of the relationship between the prior use of CCBs and 90-days mortality in patients with sepsis according to the random-effects model. (B) The sensitivity analysis showed that the studies were robust and reliable with regard to the relationship between prior CCB use and 90 -days mortality in patients with sepsis.
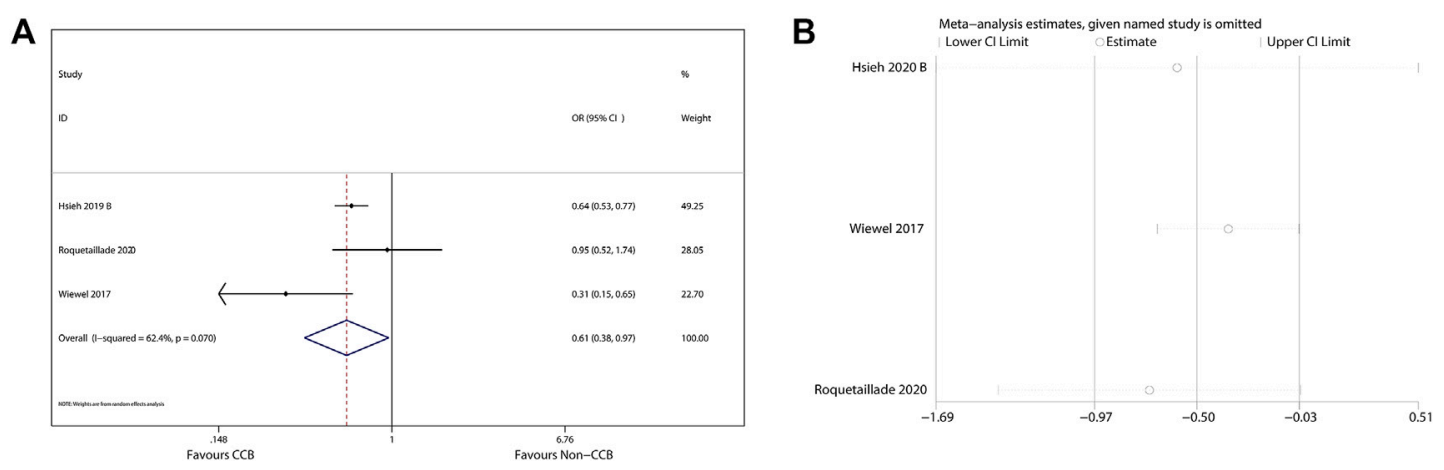

FIGURE 3 | (A) Forest plot showing the significance of the relationship between the prior use of CCBs and short-term mortality in patients with septic shock according to the random-effects model. (B) The sensitivity analysis showed that the studies were robust and reliable for the association of prior CCB use with short-term mortality in patients with septic shock.

\section{A}

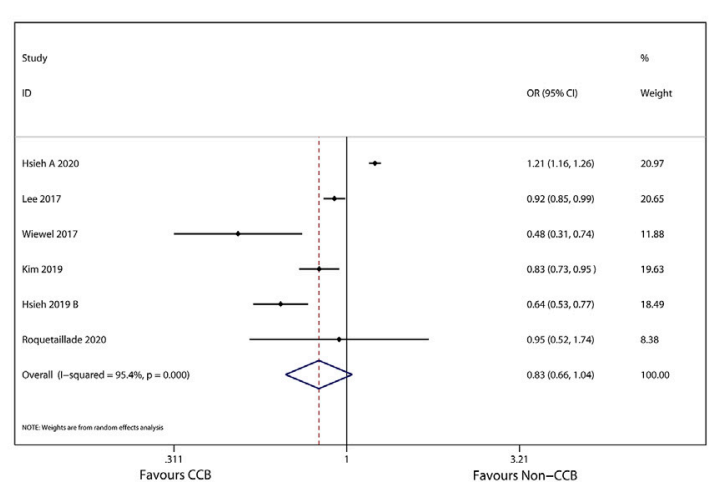

B

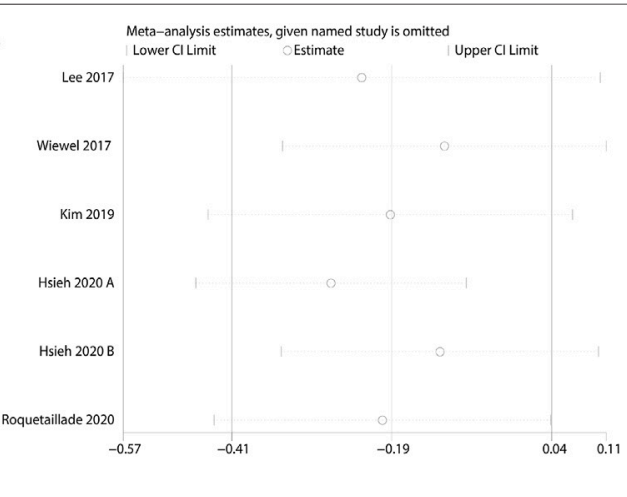

FIGURE 4 | (A) Forest plot showing the significance of the relationship between the prior use of CCBs and short-term mortality in patients with sepsis according to the random-effects model. (B) The sensitivity analysis showed that the studies were robust and reliable with regard to the relationship between prior CCB use and shortterm mortality in patients with sepsis.

Moreover, CCBs have been shown to lower oxidative burst and inducible nitric oxide synthase (iNOS) protein expression to regulate the inflammatory response (Hotchkiss et al., 1997) and ameliorate cellular injury and cardiac dysfunction. Most importantly, sepsis disrupts intracellular calcium homeostasis, which leads to endothelial injury and destroys subcellular 
structures (Duchen, 2000; Ding et al., 2013). CCBs, which are involved in targeting and blocking calcium ion overload (Meldrum et al., 1993; Song et al., 1993), could reduce intracellular $\mathrm{Ca}^{2+}$ levels and prevent cytotoxicity. However, the relationship between CCB administration and an improved prognosis of sepsis needs to be confirmed in clinical trials.

A meta-analysis is used to systematically and statistically analyze a variety of studies on the same topic. The summarized meta-analysis results have significant heterogeneity when the differences among outcomes in the included individual studies are greater than expected. In the present meta-analysis, the assessment of the risk of bias in the included studies showed a low risk of bias; thus, methodological heterogeneity did not exist.

This meta-analysis has a number of advantages. First, the sample of included septic patients was large, suggesting that the results may be stable. The large population was sufficient to conduct propensity score matching, which is a method of reducing the effects of deviations and confounding variables between the CCB and the non-CCB groups. Second, the NOS was used to assess the risk of bias. The results indicated that the studies that met the inclusion criteria for this meta-analysis had a low risk of bias. Third, we extracted the adjusted or propensity-score matched ORs and $95 \%$ CIs to calculate the pooled ORs for the effect of CCB use on mortality in an unbiased manner. Fourth, the sensitivity analysis suggested that the results were robust and reliable.

However, this meta-analysis has several limitations. Although we conducted an overall search to identify the pertinent studies as far back as possible, only five studies were included; more research may be needed to confirm this conclusion. Nevertheless, the robustness of the conclusion was supported by the sensitivity analysis. In addition, our study was limited by high heterogeneity. According to the inclusion criteria for each study, there were differences in racial and other characteristics of the participants and the timing and use of antihypertensive drugs, leading to high heterogeneity. In addition, the studies included in this meta-analysis were only observational studies, not randomized controlled trials. A certain limitation exists even if all the included cohort studies show a low risk of bias. The effectiveness of prior CCB treatment on mortality in sepsis and septic shock patients needs to be further investigated in high-quality studies.

\section{CONCLUSION}

This is the first systematic review and meta-analysis to report the association between prior CCB use and mortality in septic patients. We discussed the effects of prior CCB use on cardiovascular function and inflammation in sepsis. This meta-analysis suggests that prior $\mathrm{CCB}$ use is significantly associated with improvements in the 90-days prognosis of sepsis patients and the short-term survival of septic shock patients. However, this finding should be evaluated in future randomized controlled trials. $\mathrm{CCBs}$ remain an attractive potential method for the improvement of sepsis-related mortality.

\section{DATA AVAILABILITY STATEMENT}

The original contributions presented in the study are included in the article/Supplementary Material, further inquiries can be directed to the corresponding author.

\section{AUTHOR CONTRIBUTIONS}

All the authors contributed substantially to the work presented in this article. TS, XD, and YC conceived of the study. HL and $\mathrm{LL}$ contributed to the data interpretation. $\mathrm{XD}$ and $\mathrm{YC}$ contributed to the study protocol and wrote the article. DW, QK, and LW settled controversies. QK, LW, and TS revised the article. All authors approved the final version submitted for publication. All authors agree to be accountable for all aspects of the work, ensuring that questions related to the accuracy or integrity of any part of the work are appropriately investigated and resolved.

\section{FUNDING}

This study was supported by the, United Fund of National Natural Science Foundation of China (Grant No. U2004110), the 2021 youth talent promotion project in Henan Province (Grant No. 2021HYTP053), Leading Talents Fund in Science and Technology Innovation in Henan Province (Grant No.194200510017), Provincial Ministry Co-construction Project from Medical Scientific and Technological Research Program of Henan Province (Grant No. SBGJ2018020), the “51282" Project Leaders of Scientific and Technological Innovative Talents from Health and Family Planning Commission in Henan Province (2016-32), Science and Technology people benefit project of Zhengzhou (2019KJHM0001).

\section{ACKNOWLEDGMENTS}

We would like to thank the Chinese Evidence Based Medicine Center, West China Hospital, Sichuan University, for providing the Stata 14.0 statistical software.

\section{SUPPLEMENTARY MATERIAL}

The Supplementary Material for this article can be found online at: https://www.frontiersin.org/articles/10.3389/fphar.2021.628825/ full\#supplementary-material 


\section{REFERENCES}

Angus, D. C., and van der Poll, T. (2013). Severe Sepsis and Septic Shock. N. Engl. J. Med. 369 (21), 2063. doi:10.1056/nejmra1208623

Angus, D. C., Linde-Zwirble, W. T., Lidicker, J., Clermont, G., Carcillo, J., and Pinsky, M. R. (2001). Epidemiology of Severe Sepsis in the United States: Analysis of Incidence, Outcome, and Associated Costs of Care. Crit. Care Med. 29 (7), 1303-1310. doi:10.1097/00003246-200107000-00002

Begg, C. B., and Mazumdar, M. (1994). Operating Characteristics of a Rank Correlation Test for Publication Bias. Biometrics 50 (4), 1088-1101. doi:10. 2307/2533446

Bosson, S., Kuenzig, M., and Schwartz, S. I. (1986). Increased Survival with Calcium Antagonists in Antibiotic-Treated Bacteremia. Circ. Shock 19 (1), 69-74.

Bosson, S., Kuenzig, M., and Schwartz, S. I. (1985). Verapamil Improves Cardiac Function and Increases Survival in Canine E. coli Endotoxin Shock. Circ. Shock 16 (3), 307-316.

Brozek, J. L., Akl, E. A., Alonso-Coello, P., Lang, D., Jaeschke, R., Williams, J. W., et al. (2009). Grading Quality of Evidence and Strength of Recommendations in Clinical Practice Guidelines. Part 1 of 3. An Overview of the GRADE Approach and Grading Quality of Evidence about Interventions. Allergy 64 (5), 669-677. doi:10.1111/j.1398-9995.2009.01973.x

Clapham, D. E. (2007). Calcium Signaling. Cell 131 (6), 1047-1058. doi:10.1016/j. cell.2007.11.028

Copas, J. B., and Shi, J. Q. (2001). A Sensitivity Analysis for Publication Bias in Systematic Reviews. Stat. Methods Med. Res. 10 (4), 251-265. doi:10.1177/ 096228020101000402

Das, R., Burke, T., Van Wagoner, D. R., and Plow, E. F. (2009). L-type Calcium Channel Blockers Exert an Antiinflammatory Effect by Suppressing Expression of Plasminogen Receptors on Macrophages. Circ. Res. 105 (2), 167-175. doi:10. 1161/circresaha.109.200311

de Roquetaillade, C., Jamme, M., Charpentier, J., Chiche, J. D., Cariou, A., Mira, J. P., et al. (2020). Hemodynamic Impact of Cardiovascular Antihypertensive Medications in Patients with Sepsis-Related Acute Circulatory Failure. Augusta, Ga: Shock.

Dellinger, R. P. (2003). Cardiovascular Management of Septic Shock. Crit. Care Med. 31 (3), 946-955. doi:10.1097/01.ccm.0000057403.73299.a6

Ding, H., Cao, X.-y., Ma, X.-g., and Zhou, W.-j. (2013). Endothelial Cell Injury with Inflammatory Cytokine and Coagulation in Patients with Sepsis. World J. Emerg. Med. 4 (4), 285-289. doi:10.5847/wjem.j.issn.1920-8642.2013.04.008

Dong, Z., Saikumar, P., Weinberg, J. M., and Venkatachalam, M. A. (2006). Calcium in Cell Injury and Death. Annu. Rev. Pathol. Mech. Dis. 1, 405-434. doi:10.1146/annurev.pathol.1.110304.100218

Duchen, M. R. (2000). Mitochondria and Calcium: from Cell Signalling to Cell Death. J. Physiol. 529 (Pt 1), 57-68. doi:10.1111/j.1469-7793.2000.00057.x

Fihn, S. D., Gardin, J. M., Abrams, J., Berra, K., Blankenship, J. C., Dallas, A. P., et al. (2012). 2012 ACCF/AHA/ACP/AATS/PCNA/SCAI/STS Guideline for the Diagnosis and Management of Patients with Stable Ischemic Heart Disease: a Report of the American College of Cardiology Foundation/American Heart Association Task Force on Practice Guidelines, and the American College of Physicians, American Association for Thoracic Surgery, Preventive Cardiovascular Nurses Association, Society for Cardiovascular Angiography and Interventions, and Society of Thoracic Surgeons. J. Am. Coll. Cardiol. 60 (24), e44-e164. doi:10.1016/j.jacc.2012.07.013

Gaieski, D. F., Edwards, J. M., Kallan, M. J., and Carr, B. G. (2013). Benchmarking the Incidence and Mortality of Severe Sepsis in the United States. Crit. Care Med. 41 (5), 1167-1174. doi:10.1097/ccm.0b013e31827c09f8

Hassoun, S. M., Marechal, X., Montaigne, D., Bouazza, Y., Decoster, B., Lancel, S., et al. (2008). Prevention of Endotoxin-Induced Sarcoplasmic Reticulum Calcium Leak Improves Mitochondrial and Myocardial Dysfunction. Crit. Care Med. 36 (9), 2590-2596. doi:10.1097/ccm.0b013e3181844276

Hayashi, M., Yamaji, Y., Nakazato, Y., and Saruta, T. (2000). The Effects of Calcium Channel Blockers on Nuclear Factor Kappa B Activation in the Mesangium Cells. Hypertens. Res. 23 (5), 521-525. doi:10.1291/hypres.23.521

Higgins, J. P. T., Thompson, S. G., Deeks, J. J., and Altman, D. G. (2003). Measuring Inconsistency in Meta-Analyses. Bmj 327 (7414), 557-560. doi:10.1136/bmj. 327.7414 .557

Hotchkiss, R. S., and Karl, I. E. (1996). Calcium: a Regulator of the Inflammatory Response in Endotoxemia and Sepsis. New Horiz 4 (1), 58-71.
Hotchkiss, R. S., Bowling, W. M., Karl, I. E., Osborne, D. F., and Flye, M. W. (1997). Calcium Antagonists Inhibit Oxidative Burst and Nitrite Formation in Lipopolysaccharide-Stimulated Rat Peritoneal Macrophages. Shock 8 (3), 170-178. doi:10.1097/00024382-199709000-00004

Hotchkiss, R. S., Monneret, G., and Payen, D. (2013). Sepsis-induced Immunosuppression: from Cellular Dysfunctions to Immunotherapy. Nat. Rev. Immunol. 13 (12), 862-874. doi:10.1038/nri3552

Hsieh, M.-S., How, C.-K., Hsieh, V. C.-R., and Chen, P.-C. (2020). Preadmission Antihypertensive Drug Use and Sepsis Outcome: Impact of AngiotensinConverting Enzyme Inhibitors (ACEIs) and Angiotensin Receptor Blockers (ARBs). Shock (Augusta, Ga) 53 (4), 407-415. doi:10.1097/shk. 0000000000001382

Hunter, J. P., Saratzis, A., Sutton, A. J., Boucher, R. H., Sayers, R. D., and Bown, M. J. (2014). In Meta-Analyses of Proportion Studies, Funnel Plots Were Found to Be an Inaccurate Method of Assessing Publication Bias. J. Clin. Epidemiol. 67 (8), 897-903. doi:10.1016/j.jclinepi.2014.03.003

James, P. A., Oparil, S., Carter, B. L., Cushman, W. C., Dennison-Himmelfarb, C., Handler, J., et al. (2014). 2014 Evidence-Based Guideline for the Management of High Blood Pressure in Adults. Jama 311 (5), 507-520. doi:10.1001/jama. 2013.284427

Kim, J., Kim, Y. A., Hwangbo, B., Kim, M. J., Cho, H., Hwangbo, Y., et al. (2019). Effect of Antihypertensive Medications on Sepsis-Related Outcomes: A Population-Based Cohort Study. Crit. Care Med. 47 (5), e386-e393. doi:10. 1097/ccm.0000000000003654

Lau, J., Ioannidis, J. P. A., Terrin, N., Schmid, C. H., and Olkin, I. (2006). The Case of the Misleading Funnel Plot. Bmj 333 (7568), 597-600. doi:10.1136/bmj.333. 7568.597

Lee, C.-C., Lee, M.-t. G., Lee, W.-C., Lai, C.-C., Chao, C. C.-T., Hsu, W.-T. H., et al. (2017). Preadmission Use of Calcium Channel Blocking Agents Is Associated with Improved Outcomes in Patients with Sepsis. Crit. Care Med. 45 (9), 1500-1508. doi:10.1097/ccm.0000000000002550

Li, G., Qi, X. P., Wu, X. Y., Liu, F. K., Xu, Z., Chen, C., et al. (2006). Verapamil Modulates LPS-Induced Cytokine Production via Inhibition of NF-Kappa B Activation in the Liver. Inflamm. Res. 55 (3), 108-113. doi:10.1007/s00011-005-0060-y

Li, X.-Q., Cao, W., Li, T., Zeng, A.-G., Hao, L.-L., Zhang, X.-N., et al. (2009). Amlodipine Inhibits TNF- $\alpha$ Production and Attenuates Cardiac Dysfunction Induced by Lipopolysaccharide Involving PI3K/Akt Pathway. Int. Immunopharmacol. 9 (9), 1032-1041. doi:10.1016/j.intimp.2009.04.010

Martin, G. S., Mannino, D. M., Eaton, S., and Moss, M. (2003). The Epidemiology of Sepsis in the United States from 1979 through 2000. N. Engl. J. Med. 348 (16), 1546-1554. doi:10.1056/nejmoa022139

Mason, R. P., Mak, I. T., Walter, M. F., Tulenko, T. N., and Mason, P. E. (1998). Antioxidant and Cytoprotective Activities of the Calcium Channel Blocker Mibefradil. Biochem. Pharmacol. 55 (11), 1843-1852. doi:10.1016/s00062952(98)00070-7

Meldrum, D. R., Ayala, A., and Chaudry, I. H. (1993). Mechanism of Diltiazem's Immunomodulatory Effects after Hemorrhage and Resuscitation. Am. J. Physiol. Cell Physiol. 265 (2 Pt 1), C412-C421. doi:10.1152/ajpcell.1993. 265.2.c412

Mustafa, S. B., and Olson, M. S. (1999). Effects of Calcium Channel Antagonists on LPS-Induced Hepatic iNOS Expression. Am. J. Physiol. Gastrointestinal Liver Physiol. 277 (2), G351-G360. doi:10.1152/ajpgi.1999.277.2.g351

Németh, Z. H., Haskó, G., Szabó, C., Salzman, A. L., and Vizi, E. S. (1998). Calcium Channel Blockers and Dantrolene Differentially Regulate the Production of Interleukin-12 and Interferon- $\gamma$ in Endotoxemic Mice. Brain Res. Bull. 46 (3), 257-261. doi:10.1016/s0361-9230(98)00005-7

Ou, S.-M., Chu, H., Chao, P.-W., Lee, Y.-J., Kuo, S.-C., Chen, T.-J., et al. (2016). Long-Term Mortality and Major Adverse Cardiovascular Events in Sepsis Survivors. A Nationwide Population-Based Study. Am. J. Respir. Crit. Care Med. 194 (2), 209-217. doi:10.1164/rccm.201510-2023oc

Rhodes, A., Evans, L. E., Alhazzani, W., Levy, M. M., Antonelli, M., Ferrer, R., et al. (2017). Surviving Sepsis Campaign: International Guidelines for Management of Sepsis and Septic Shock: 2016. Crit. Care Med. 45 (3), 486-552. doi:10.1097/ CCM.0000000000002255

Singer, M., Deutschman, C. S., Seymour, C. W., Shankar-Hari, M., Annane, D., Bauer, M., et al. (2016). The Third International Consensus Definitions for Sepsis and Septic Shock (Sepsis-3). Jama 315 (8), 801-810. doi:10.1001/jama. 2016.0287 
Song, S. K., Karl, I. E., Ackerman, J. J., and Hotchkiss, R. S. (1993). Increased Intracellular Ca2+: a Critical Link in the Pathophysiology of Sepsis?. Proc. Natl. Acad. Sci. 90 (9), 3933-3937. doi:10.1073/pnas.90.9.3933

Stroup, D. F., Berlin, J. A., Morton, S. C., Olkin, I., Williamson, G. D., Rennie, D., et al. (2000). Meta-analysis of Observational Studies in EpidemiologyA Proposal for Reporting. Jama 283 (15), 2008-2012. doi:10.1001/jama.283.15. 2008

Stuck, A. E., Rubenstein, L. Z., Wieland, D., Vandenbroucke, J. P., Irwig, L., Macaskill, P., et al. (1998). Bias in Meta-Analysis Detected by a Simple, Graphical. Bmj 316 (7129), 469. doi:10.1136/bmj.316.7129.469

Sueta, D., Tabata, N., and Hokimoto, S. (2017). Clinical Roles of Calcium Channel Blockers in Ischemic Heart Diseases. Hypertens. Res. 40 (5), 423-428. doi:10. 1038/hr.2016.183

Tan, K., Harazim, M., Tang, B., McLean, A., and Nalos, M. (2019). The Association between Premorbid Beta Blocker Exposure and Mortality in Sepsis-A Systematic Review. Crit. Care (London, England) 23 (1), 298. doi:10.1186/ s13054-019-2562-y

Vincent, J.-L., Rello, J., Marshall, J., Silva, E., Anzueto, A., Martin, C. D., et al. (2009). International Study of the Prevalence and Outcomes of Infection in Intensive Care Units. Jama 302 (21), 2323-2329. doi:10.1001/jama.2009.1754

Wells, G. A., and O'Connell, D. (2014). The New-Ottawa Scale (NOS) for Assessing the Quality of Nonrandomized Studies in Meta-Analyses. Available at: www.ohri.ca/ programs/clinical_epidemiology/oxford.asp (Accessed October 16, 2014).

Wiewel, M. A., van Vught, L. A., Scicluna, B. P., Hoogendijk, A. J., Frencken, J. F., Zwinderman, A. H., et al. (2017). Prior Use of Calcium Channel Blockers Is
Associated with Decreased Mortality in Critically Ill Patients with Sepsis. Crit. Care Med. 45 (3), 454-463. doi:10.1097/ccm.0000000000002236

Wyska, E. (2009). Pretreatment with $\mathrm{R}(+)$-verapamil Significantly Reduces Mortality and Cytokine Expression in Murine Model of Septic Shock. Int. Immunopharmacol. 9 (4), 478-490. doi:10.1016/j.intimp.2009.01.013

Zhang, W.-J., Wei, H., Hagen, T., and Frei, B. (2007). -Lipoic Acid Attenuates LPSInduced Inflammatory Responses by Activating the Phosphoinositide 3-kinase/ Akt Signaling Pathway. Proc. Natl. Acad. Sci. 104 (10), 4077-4082. doi:10.1073/ pnas.0700305104

Zhu, X., Bernecker, O. Y., Manohar, N. S., Hajjar, R. J., Hellman, J., Ichinose, F., et al. (2005). Increased Leakage of Sarcoplasmic Reticulum $\mathrm{Ca}^{2+}$ Contributes to Abnormal Myocyte Ca2+ Handling and Shortening in Sepsis. Crit. Care Med. 33 (3), 598-604. doi:10.1097/01.ccm.0000152223.27176.a6

Conflict of Interest: The authors declare that the research was conducted in the absence of any commercial or financial relationships that could be construed as a potential conflict of interest.

Copyright (C) 2021 Ding, Cui, Liang, Wang, Li, Kan, Wang and Sun. This is an openaccess article distributed under the terms of the Creative Commons Attribution License (CC BY). The use, distribution or reproduction in other forums is permitted, provided the original author(s) and the copyright owner(s) are credited and that the original publication in this journal is cited, in accordance with accepted academic practice. No use, distribution or reproduction is permitted which does not comply with these terms. 